\title{
FIFTH DOCUMENTED \\ GREAT GRAY OWL NEST \\ IN SASKATCHEWAN
}

C. STUART HOUSTON, 863 University Drive, Saskatoon, Saskatchewan, S7N $0 J 8$ and KELWIN A. WYLIE, \#43, 24 Central Place, Saskatoon, Saskatchewan. S7N $2 S 2$.

The Great Gray Owl is the most beautiful of our owls. One of the greatest thrills of $C$. Stuart Houston's banding career $w^{\text {'s }}$ on 6 January 1956 when he becaıne, he was later told, only the third bander in North America to band a Great Gray Owl. The owl had been trapped unharmed by Keith Thue at the Beaver Creek Game Farm south of Saskatoon; it was released near the Borden Bridge. ${ }^{3}$ This stimulated Houston to compile all available Saskatchewan specimen records and sightings to that date. ${ }^{4}$

Many years passed before subpermittee Kelwin Wylie banded a Great Gray that had been temporarily stunned after flying into a car near the Turtle Lake junction on Highway \#4, north of Glaslyn on 8 June 1983. Ironically the message awaited him when he reached Saskatoon after participating in the planning trip for the Turtle Lake summer meeting of the Saskatchewan Natural History Society; he turned around to drive most of the night to and from Carol Burnard's Moose Country service station at the junction. This Great Gray Owl did not last long: 48 hours after its banding and release, it was hit and killed by another vehicle on the same highway.

Since the authors share an interest in banding nestling owls, we have for years looked forward to an opportunity to band nestling Great Grays. Wayne C. Harris has on several occasions located pairs of owls in Febru- ary and March that seemed to be on territory near a highway, but by April and May no nest could be found. Bert Dalziel and Bruce Donovan have similarly had no success in the Torch River area.

The first documented Saskatchewan nest of a Great Gray Owl was found near Carlton on 19 June 1902, the two eggs collected by George McCrurry (set \#35471, Western Foundation of Vertebrate Zoology, Los Angeles). ${ }^{1}$

The second record, of a single egg on 5 July 1907 at Quill Lake (Field Museum, \#7095) seemed improbable on several grounds: it was only a single egg, it was much too late in the season, and it was too far south. ${ }^{1}$ John W. Fitzpatrick of the Field Museum in Chicago resolved some of the concerns by sending us a xerox copy of two data slips from the R.M. Barnes coliection:

"Species: Great Gray Owl. Identity positive. Incubation: Addled, 2 young. Collected by E.R. Clark for C.P.F. Nest in large elm tree on side of Lake. Old nest of Hawk, flattened of sticks. $40 \mathrm{ft}$. up, and pretty dirty." The late date is thus explained by the presence of an addled egg, along with two young.

Nonetheless, some doubt persists. Herbert C. Clark was the teamster, guide and general helper to the John F. Ferry and R. Magoon Barnes col- 
lecting expedition to Quill Lake in 1909. The Clarks lived on the shore of Quill Lake and Herbert's younger brother, also interested in birds, was only 13 in $1907 .{ }^{2}{ }^{5}$ If either Clark had sold this egg to Barnes in 1909, why did Ferry not list the species in his 1910 list? In 1909, prairie fires were no longer common, yet crow nests were still only 6 or 7 feet from the ground in regenerating aspen. ${ }^{2}$ While one large tree might have survived fires through being near the lake, elms are not native on the Quill Lakes. One wonders whether a Great Gray Owl would have nested on the shores of a large alkaline lake in nearly open prairie habitat.

The third nest was found by R.D. Symons in 1937 "at the canyon on the Bainbridge River in the Pasquia Forest ..the nest had once been built by a red-tailed hawk." 18

The fourth nest was found by Clifford Law in the first week of May 1949 in the Fort à la Corne Game Preserve, 8 miles southwest of Choiceland. The nest in a former hawk's nest, was about 20 feet up in an aspen, in a 5acre stand of aspen and spruce, surrounded on three sides by open meadows. ${ }^{6}$

Our luck began to turn, though we did not at the time appreciate it, when Bob Finley accompanied us on the first day of Great Horned Owl banding on 5 May 1984. A week later, Bob was hunting Black Bear with bowand-arrow in the forest reserve east of Neeb, Saskatchewan. While resting at the main camp Bob met local trapper Garry Dyck. They struck up a conversation and Bob happened to mention his owl banding a week earlier. Garry asked Bob whether we would come as far as the Meadow Lake area to band owls. Bob correctly stated that we would not travel that far for a Great Horned Owl nest. "Oh, but I know the horned owl, and my nest is another

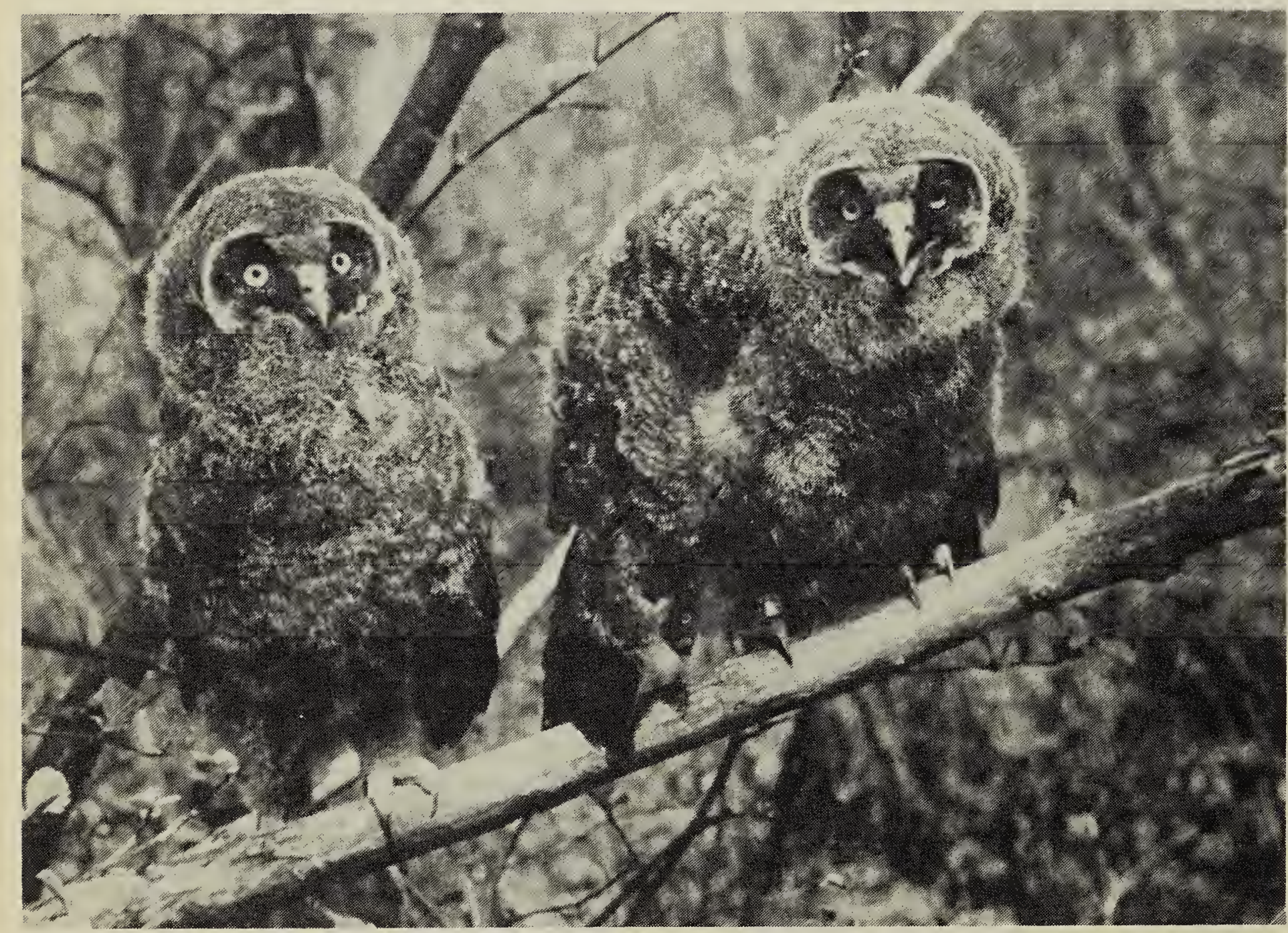

Young Great Gray Ow/s after banding

C.S. Houston 
kind of owl - large, dark, without ear tufts."

Bob arranged for fellow Conservation Officer Dennis Engele to visit the nest and confirm the identity of the parent birds. The Meadow Lake area was then inundated with $102 \mathrm{~mm}$ of rain, the roads became impassable, Garry Dyck could not get to Meadow Lake for groceries, and Dennis Engele could not get out to Garry's trapper's cabin. Finally on 21 May Engele managed the trip on a three-wheel allterrain vehicle and next day notified us of the positive identification of a Great Gray nest with three young, one already out of the nest on a branch. That was the good news.

Then came the bad news. Dennis advised us that the 12-mile trip on forest trails would be impassable even for my four-wheel-drive Wagon. We therefore needed an amphibious four-passenger all-terrain vehicle (ATV), to get through many mudholes and to ford the flooded streams. Enquiries suggested that the Argo ATV would fit the bill if one could be rented. A phone call to Adrian Fleury in Edmonton produced a list of Saskatchewan dealers and the pleasant news that the Saskatoon dealer, Saskatoon All-Terrain, would probably rent such a vehicle by the day. A phone call to this dealership brought a bright "Nice to hear from you, Dr. Houston" from manager Ron Herman, who was originally from Houston's home town of Yorkton. He rented us the Argo for a day and loaned us a trailer.

Early on 26 May the authors, with Mary Houston, left Saskatoon, picked up Finley in North Battleford, and Engele and his assistant Dale Wyatt at Meadow Lake. On the fire-guard east of Neeb we backed the Argo off the trailer and headed down the trail, convoyed by Engele and Wyatt on three-wheel ATVs. We picked up Garry Dyck at his cabin, bringing the party to seven.

When we approached the nest, we found the largest Great Gray Owl young perched on a horizontal branch about 12 feet above our heads and about 100 yards from the nest. The second bird was far out on a limb above the nest, which was 43 feet above the ground in the fork of a large aspen. The third nestling was still in the nest, which we believe from its size and construction was more likely the nest of a Goshawk than a Redtailed Hawk. The nest tree itself was on dry ground and surrounded by other aspens. The nest tree thus was not in a tamarack swamp as is often the case, but nearby there was a tamarack swamp, a substantial meadow and a small lake, fulfilling the usual Great Gray requirements. ${ }^{7}$

Soon the smaller male adult came with a vole in his bill and transferred it to the female. She looked nervously at us and swallowed the vole herself. On the previous visit Engele had observed two such transfers, but in each case on receipt of the vole the female had fed it to one of the young.

After we caught, banded and replaced the oldest young on the horizontal branch, Wylie climbed the nest tree. Both remaining owls jumped from the tree and glided down to the ground more expertly than any Great Horned Owl at a similar stage of feathering (Figure 1). Meanwhile the female parent came and sat only four feet from the nest. The two young on the ground were then hoisted up to the nest in a backpack. We marvelled at the beauty of both adults and young, much darker than any Great Horned Owl, at their noiseless flight, and at their relative tameness.

Pellets collected from below the nest for analysis contained the following: 19 Meadow Voles (minimum number based on skulls), 9 Northern Bog Lemmings (minimum number 
based on lower jaws), 2 Gapper's Redbacked Voles (minimum number based on lower jaws) and 1 snail, probably swallowed by one of the voles, since it was too small for the owl to have ingested purposely, or perhaps even seen.

All told, we spent six hours in the Meadow Lake area, and four hours in travel each way. We arrived back in Saskatoon at 9:00 p.m., two hours too late for a scheduled banquet which we were told had been sumptuous. But we had banqueted at a different type of feast - our never-to-be forgotten first nest of a Great Gray Owl.

\section{Acknowledgements}

We wish to thank R.W. Nero for loaning K. Michael Collins' University of Manitoba thesis appendix, listing known North American breeding records of the Great Gray Owl, and Lloyd F. Kiff of the Western Foundation of Vertebrate Zoology in Los Angeles and John W. Fitzpatrick of the Field Museum in Chicago for additional nest record data.

Bob Finley, Garry Dyck, Dennis Engele and Ron Herman together made the banding trip possible. Hugh C. Smith, Curator of Mammalogy at the Alberta Provincial Museum in Edmonton, analysed the pellets for us.

${ }^{1}$ COLLINS, K.M. 1980. Aspects of the Biology of the Great Gray Owl. M. Sc. thesis, University of Manitoba, Winnipeg.

${ }^{2}$ FERRY, J.F. 1910. Birds observed in Saskatchewan during the summer of 1909. Auk 27: 185-204.

${ }^{3}$ HOUSTON, C.S. 1956. Great Gray Owl banded at Saskatoon. Blue Jay 14: 11.

${ }^{4}$ HOUSTON, C.S. 1957. The Great Gray Owl in Saskatchewan. Blue Jay 15: 150-153.

${ }^{5}$ HOUSTON, C.S. 1980. Early Quill Lake ornithologists. Blue Jay 38: 219-220.

${ }^{6}$ LAW, C. 1960 . The Great Gray Owl of the woodlands. Blue Jay 18: 14-16.

${ }^{7}$ NERO, R.W. 1980. The Great Gray Owl. Washington: Smithsonian.

${ }^{8}$ SYMONS, R.D. 1967. Hours and the Birds - a Saskatchewan Record. Toronto: University of Toronto Press. p. 136.

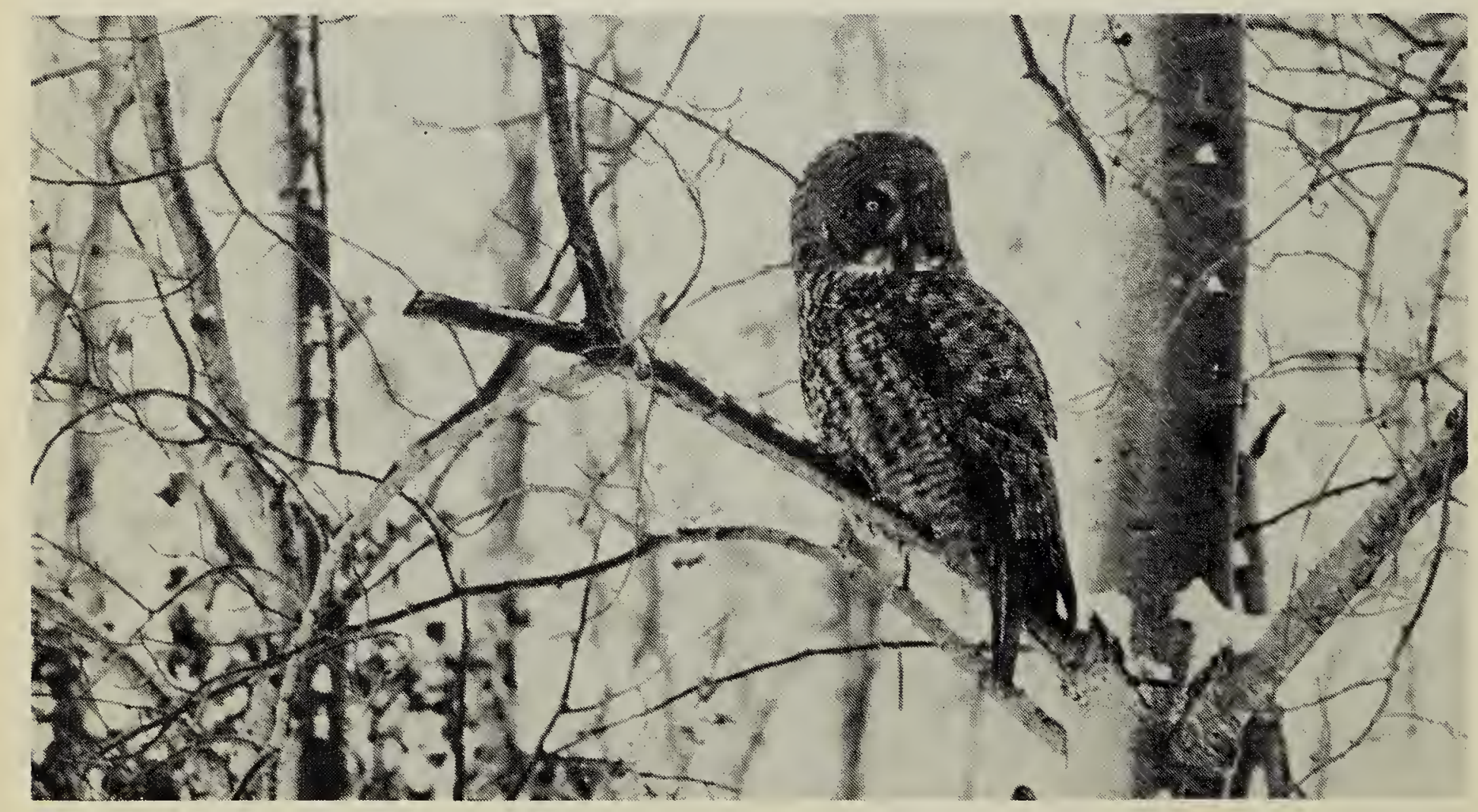

Hunting birds often perch in deciduous trees in winter

Robert R. Taylor 